\title{
PERAN BAHASA ARAB \\ DALAM PENGEMBANGAN ILMU DAN PERADABAN ISLAM
}

\author{
Taufiq Anshori, SS, M.Pd \\ E-mail taufiq86anshori@gmail.com
}

\begin{abstract}
This study aims to clarify the role of the Arabic language in advancing science and Islamic civilization through a library study of the history of the Arabic language a long the ages. The approach used to analyze the data of Arabic language development is historical approach combined with content analysis approach. The study has come to the conclusion that there are ive important roles of Arabic language. Firstly, it served as the language of the union among the people and the Arab tribes. Secondly, Arabic preserved the richness of local Arabic cultures through all times. Thirdly, Arabic used as a media for educational and scienti ic study, possitioning it as the language of science and technology. Fourthly, Arabic is as a tool of communication among the people and tribes and generations. Fifthly, Arabic is accepted as a standardized language for Islamic knowledge and modern sciences.
\end{abstract}

\section{Pendahuluan}

Bahasa Arab adalah bahasa yang paling banyak menyandang atribut. Selain merupakan bahasa kitab suci al-Qur'an dan Hadis, bahasa Arab adalah bahasa agama untuk umat Islam, bahasa resmi Perserikatan Bangsa-bangsa (PBB), bahasa nasional lebih dari 25 negara di kawasan Timur Tengah, lughah al-dhâd, dan bahasa warisan sosial budaya (lughah al-turâts). Jabir Qumaihah, misalnya, menegaskan bahwa bahasa Arab merupakan bahasa yang mendapat garansi dan "proteksi Ilahi" (al-himâyah al-Ilâhiyyah), seiring dengan digunakannya sebagai "wadah ekspresi al-Qur'an" (wi ' $\hat{a}$ ' al-Qur'ân). Bahasa Arab juga dipandang sebagai suatu bahasa yang sangat orisinal; tidak memiliki masa kanak-kanak sekaligus masa renta (lughah ashîlah, laisa lahâ thufûlah wa laisa lahâ syaikhûkhah).

Meskipun sebagai kalam Allah yang diwahyukan kepada Nabi Muhammad Saw, bahasa Arab (al-Qur'an) tetap merupakan bahasa manusia atau produk budaya bangsa Arab. Ia bukan bahasa Tuhan atau malaikat. Sebagai produk dan subsistem budaya, bahasa Arab mempunyai dimensi linguistik, humanistik, sosio-kultural, dan pragmatik. Bahasa Arab pada dasarnya tunduk kepada (mengikuti) sistem linguistik yang telah menjadi kesepakatan penutur bahasa ini (nâthiq bi al-'Arabiyyah), baik sistem fonologi, leksikologi, morfologi, sintaksis maupun semantik. Kendatipun sebagai bahasa al-Qur'an, bahasa Arab tidak perlu disakralkan atau dianggap sebagai bahasa suci (lughah muqaddasah), tetapi cukup diposisikan sebagai bahasa terhormat dan diberi apresiasi tinggi (lughah mu'azhzhamah) karena ia merupakan bahasa al-Qur'an, bahasa yang digunakan dalam sebagian besar ibadah ritual, dan bahasa budaya Islam (lughah al-tsaqâfah al-Islâmiyyah). Pandangan ini mengisyaratkan bahwa bahasa Arab adalah sebuah sistem sosial-budaya yang terbuka untuk dikaji, dikritisi, dan dikembangkan.

Sebagai subsistem budaya, bahasa Arab merupakan salah satu bahasa (rum-pun) Semit (usrah al-Lughât al-Sâmiyyah) yang dinilai paling tua dan tetap eksis hingga sekarang. 
Kemampuan bahasa Arab tetap eksis hingga sekarang, antara lain, disebabkan oleh posisinya sebagai bahasa pilihan Tuhan untuk kitab suci-Nya (al-Qur'an). Meskipun fungsinya lebih merupakan media ekspresi kitab suci bagi masyarakat Arab (tempat/lokasi Nabi Muhammad Saw. mendakwahkan ajaran Islam), bahasa Arab - dalam hal ini bahasa suku Arab Quraisy sebagai bahasa standar dan lingua franca (lughah musytarakah) saat itu-merupakan bahasa yang telah mencapai puncak "kedewasaan dan kematangannya". Hal ini, antara lain dibuktikan dari penggunaan bahasa Arab sebagai bahasa sastra dan pemersatu pada masa Jahiliyah. Selain itu, bahasa Arab hingga kini juga menjadi bahasa yang mampu me-nampung kebutuhan para penggunanya dan menyerap berbagai perkembangan ilmu pengetahuan dan teknologi dalam berbagai bidang. Hal ini antara lain disebabkan oleh watak dan karakteristik bahasa Arab yang elastis (murûnah), menganut sistem derivasi dan analogi (isytiqâq wa qiyâs) yang komprehensif, dan memiliki perbendaharaan kata (tsarawât lughawiyyah wa mufradât) yan g kaya.

\section{Posisi Bahasa Arab dalam Pengkajian Islam}

Allah Swt. memilih bahasa Arab sebagai bahasa kitab suci-Nya bukan semata-mata karena masyarakat tempat Nabi Muhammad Saw. ditugasi sebagai Rasul mengunakan bahasa Arab (bi lisân qawmihi) melainkan juga karena bahasa Arab dipandang mampu dan layak untuk mewadahi dan mengekspresikan pesan-pesan Ilahi yang abadi (eternal) dan universal. Bila kemudian bahasa Arab menjadi bahasa lebih dari 22 negara di kawasan Timur Tengah dan sebagian benua Afrika, lalu menjadi bahasa resmi sekaligus bahasa internasional yang digunakan sebagai bahasa kerja di PBB, maka faktor utamanya selain turut terpelihara bersamaan dengan "garansi dan proteksi Ilahi" mengenai pemeliharaan al-Qur'an tersebut adalah elan vital (semangat juang, daya dorong) dan motivasi religius umat Islam untuk memahami pesan-pesan Ilahi dan Tradisi (Sunnah) Nabi Saw. Di samping itu, tentu saja, umat Islam mendapati bahasa Arab tampil sangat elegan, fleksibel, dan bernilai sastra tinggi dalam mentransmisikan berbagai karya intelektual Muslim dalam bentuk teks-teks, baik buku maupun manuskrip, yang hingga kini masih menjadi bahan kajian dan sumber inspirasi pemikiran Islam yang sangat berharga.

Dalam konteks ini, dapat ditegaskan bahwa bahasa Arab mempunyai posisi sangat penting dan strategis dalam pengkajian dan pengembangan ilmu-ilmu keislaman, bahkan dalam pengembangan peradaban Islam. Menarik dicermati bahwa sebagian besar karya intelektual Muslim yang non-Arab (tidak berkebangsaan Arab), seperti Sîbawaih (w. $180 \mathrm{H}$ ), al-Fârabî(w. 339 H), Ibn Sînâ(w. 428 H), Ibn Miskawaih (932-1030 M), al-Ghazâlî (w. 1111 M), dan lain sebagainya ditulis dalam bahasa Arab, karena pada waktu itu bahasa Arab merupakan bahasa ilmu pengetahuan. Dengan kata lain, bahasa Arab bukan semata-mata bahasa komunikasi harian antarpenuturnya, melainkan bahasa ilmu pengetahuan yang mampu mewadahi dan mentransmisikan wacana pemikiran dan karya-karya keilmuan.

Dalam perkembangannya, terutama setelah Islam tersebar ke luar Jazirah Arabia, bahasa Arab tidak hanya menjadi bahasa lokal, tetapi menjadi bahasa internasional, mengikuti universa-litas Islam. Wilayah-wilayah baru yang ditundukkan atau dibebaskan oleh kekuasaan Islam, meskipun sebelumnya telah memiliki bahasa resmi, akhirnya terarabkan (menggunakan bahasa Arab). Salah satu faktor yang membuat terjadinya "simbiosismutualisme" antara bahasa Arab dan Islam adalah karena posisi bahasa Arab sebagai bahasa 
agama (lughah al-dîn) dan bahasa pembebas (lughah al-fâtih al-jadîd), yang dalam ungkapan Ibn Khaldun, bahasa Arab dinilai sebagai "lughah ahl al-amshâr tâbi'ah li al-dawlah" (bahasa lokal yang mengikuti bahasa Negara, dalam hal ini Arab).

Dalam generasi awal umat islam tampaknya sangat serius dan intens dalam upaya memahami al-Qur'an dan Sunnah Nabi, sehingga mereka senantiasa saling belajar, berdiskusi dan bertanya jawab mengenai makna-makna (tafsir) berbagai kata atau ayat al-Qur'an. Setelah Islam berkembang luas ke berbagai daerah bekas "hegemoni sosial politik dan intelektual Persia" di sebelah timur Jazirah Arab dan "hegemoni Romawi" di sebelah barat, banyak non-Arab yang "terpaksa" harus beradaptasi dan mempelajari bahasa Arab. Keinginan untuk mempelajari bahasa Arab terutama didorong oleh semangat untuk mengetahui isi al-Qur'an dan memahami ajaran Islam pada umumnya.

Semua itu, pada gilirannya, memicu dan memacu lahirnya berbagai disiplin ilmu dalam Islam. Terjadinya berbagai perdebatan teologis dan perbedaan mazhab fiqih pada awal abad kedua hijriyah juga mendorong banyak kalangan mengkaji bahasa Arab dengan tujuan memahami sumber-sumber ajaran Islam, terutama al-Qur'an dan al-Sunnah. Percampuran dan akulturasi budaya (al-mutsâqafah) antara bangsa Arab dan non-Arab yang disemangati oleh komitmen dan keinginan kuat memahami Islam juga menjadikan bahasa Arab sebagai bahasa yang banyak dipelajari, sehingga dorongan untuk "mengilmukan" bahasa Arab pun muncul, terutama setelah banyaknya kasus lahnn (kesalahan berbahasa Arab) di kalangan nonArab.

Meskipun perkembangan dan pertumbuhan ilmu-ilmu ke-islaman masih menjadi bahan perdebatan, dapat ditegaskan bahwa dorongan untuk menyusun dan merumuskan ilmu bahasa Arab muncul paling dini dari "rahim" dunia Islam. Jika memang benar bahwa "Alîibn Abî Thâlib (600-661 M) adalah khalifah yang menginstruksikan Abû al-Aswad al-Du'alî(16$69 \mathrm{H}$ ) untuk menyusun kaidah-kaidah praktis mengenai bahasa Arab, utamanya untuk kepentingan pembacaan al-Qur'an bagi bangsa non-Arab ('ajam) agar terhindar dari kesalahan (la $\underline{h} n)$, maka ilmu bahasa Arablah-khususnya ilmu nahwu dan sharaf-yang pertama kali mencuat dalam sejarah ilmu di dunia Islam. Hal ini diperkuat oleh fakta bahwa penyusun karya mengenai nahwu dan sharaf pertama secara sistematis adalah Sibawaih yang wafat pada tahun $180 \mathrm{H}$. Ilmu-ilmu keislaman saat itu belum sampai pada tingkat kematangan-nya, karena memang baru dalam taraf konsolidasi dan kodikasi, seperti hadits, iqh dan ilmu kalam.

Posisi bahasa Arab menjadi lebih strategis dan bahkan menjadi bahasa pendidikan dan kebudayaan, terutama karena sebagian ulama Islam juga menguasai bahasa Suryani, Yunani, Persia, dan India. Penguasaan bahasa asing, bagi ulama Arab, sekaligus menjadi pintu masuk berbagai bidang ilmu yang sebelumnya dikembangkan oleh bangsa Yunani, Persia, dan India. Bahasa Arab sebagai bahasa akademik di berbagai lembaga pendidikan yang ada juga turut menjadi faktor akselerasi (percepatan) persebaran bahasa Arab bagi banyak kalangan. Pusat-pusat pendidikan dan pengkajian yang telah ada sebelum pemerintahan Islam menakluk-kan mereka, seperti Jundisapur, Iskandaria, Antokia, Harran, dan sebagainya yang banyak dikembangkan oleh ulama Suryani, kemudian menjadi pusat pengkajian dan pengembangan bahasa Arab, lebih-lebih saat dilakukan gerakan penerjemahan karya-karya asing (Yunani, Persia, Suryani dan India) ke dalam bahasa Arab. 


\section{Bahasa Arab dan Peradaban Islam}

Pada masa Khalifah Malik ibn Marwân, bahasa Arab diposisikan sebagai bahasa negara (dawlah Umayyah), khususnya sebagai bahasa resmi dan bahasa administrasi pemerintahan. Meskipun Arabisasi ini memang agak bernuansa politis, karena Bani Umayyah tergolong memiliki "fanatisme yang kuat" (ta'ashshub qawiy) terhadap kesukuan dan kearabannya, dampaknya cukup luas dan signifikan. Pengaruh bahasa Persia, Qibtia, dan bahasa Romawi sebagai bahasa administrasi di masa lalu (sebelum khilafah Umawiyah) kemudian digantikan oleh bahasa Arab.

Bangsa Arab memang dapat dianggap bangsa "pemenang bukan pecundang". Karena itu, ketika berbagai istilah dalam bidang administrasi, ekonomi, sosial, dan politik didominasi, terutama, oleh bahasa Romawi dan Persia, Khalifah Abdul Malik bin Marwan menemukan momentumnya yang tepat untuk memulai arabisasi Negara ( a $^{6} \mathrm{rîb}$ al-dawlah), yang pada gilirannya diikuti dengan arabisasi administrasi pe-merintahan (ta'rîb al-dawâwîn), mata uang, bahkan arabisasi budaya. Dari gerakan arabisasi inilah, cikal bakal teoritisasi dan dinamisasi ilmu-ilmu dalam bahasa Arab itu dimulai.

Implikasinya lebih jauh adalah bahwa karya-karya sastra (sya'ir/puisi, natsr/ prosa) yang bernuansa kearaban banyak bermunculan. Romantisme "kejayaan baha-sa Arab era Jahiliyah" kembali menemukan bentuknya. Mata uang resmi diarabkan (dalam bentuk dinâr dan dirhâm) yang semula berbahasa Persia atau Romawi-Yunani. Berbagai transaksi sosialekonomi di hampir seluruh wilayah dinasti Umawi juga menggunakan bahasa Arab. Dengan demikian, pada masa itu, bahasa Arab tidak sekadar bahasa agama, melainkan juga sebagai bahasa negara: bahasa administrasi, birokrasi, diplomasi, dan bahasa transaksi sosial ekonomi. Di antara dîwân (semacan kantor kementerian) yang diarabisasikan ketika itu adalah Kementerian Perpajakan, Kementerian Pos dan Telekomunikasi, dan Kementerian Keuangan. Berbagai arabisasi istilah, ungkapan, dan tradisi (budaya) juga terjadi dalam berbagai instansi pemerintah lainnya. Atas dasar itu, dapat ditegaskan bahwa gerakan arabisasi, yang semula merupakan kebijakan politik, ternyata men-jadi cikal bakal gerakan intelektual, gerakan kultural, pengembangan ilmu pengetahuan dan peradaban. Ketika dinasti Abbasiyah berkuasa, menggantikan dinasti Umayyah, orientasi dan tradisi keilmuan mendapat ruang dan momentumnya yang relevan dan signi ikan. Bersamaan dengan itu, atas kebijakan khalifah Hârûn al-Rasyîd (786-809 M) dan terutama al-Ma'mûn (813-833 M), gerakan "intelektualisasi" berjalan mulus dan memperlihatkan kesuksesan yang luar biasa. Proses intelektualisasi dan sivilisasi (pemeradaban) umat Islam ini, tentu saja tidak dapat dipisahkan dari pergumulan dan interaksi sosial budaya dan pemikiran antara umat Islam dengan berbagai bangsa lain, utamanya bangsa-bangsa bekas dominasi Romawi (seperti Suriah, Turki, Palestina, Yordania) dan Persia yang memang meninggalkan khazanah keilmuan di berbagai bidang keilmuan. Yang menarik dalam konteks ini adalah bahwa sang khalifah yang menginstruksikan gerakan penerjemahan besar-besaran berbagai kar-ya ilosof Yunani dan ilmuwan Persia dan India ke dalam bahasa Arab. Di antara buku yang diarabkan saat itu adalah al-Tasyrîh (Pembedahan) karya Jalinus, al-Handasah (Arsitektur) karya Plato, al-Majesti karya Ptolemios, dan al-Samâ' ${ }^{6}$ wa al-'Âlam karya Aristoteles. Kolaborasi ulama dan umara' terbukti membuahkan proses dan dinamika keilmuan yang sangat pesat sehingga 
dalam waktu yang relatif singkat kemajuan peradaban Islam dalam berbagai bidang dapat diwujudkan. Dialektika pengetahuan dan kekuasaan ini ditopang oleh teologi rasional negara (Mu'tazilah) yang ber-pengaruh besar terhadap dinamisasi pengembangan ilmu dan peradaban Islam.

Gerakan penerjemahan tersebut tidak hanya melibatkan sumber daya manusia (SDM) dari kalangan umat Islam saja, melainkan juga melibatkan atau ada semacam usaha "menyewa" atau memanfaatkan para penerjemah dari kalangan Nasrani, seperti Hunain ibn Ishâq (808-873 M), dan Ishaq ibn Hunain untuk menekuni dan mendedikasikan keahliannya dalam menerjemahkan karya-karya dari bahasa Yunani dan Suryani ke dalam bahasa Arab. Kerjasama akademik lintas agama dan budaya ini membuktikan bahwa Islam dan peradabannya memang terbuka dan bisa bekerjasama secara sinergis dengan siapapun, termasuk ilmuwan Yahudi, yang pada umumnya menguasai bahasa Suryani. Hal ini sekaligus menjadi isyarat kuat bahwa untuk bisa maju dalam bidang ilmu pengatahuan dan peradaban, umat Islam harus terbuka dan bersedia melakukan kerjasama atau kemitraan keilmuan dengan siapapun.

Posisi bahasa Arab sebagai bahasa ilmu pengetahuan Islam, bahasa pendidikan, dan kebudayaan pada masa keemasan Islam tersebut dipandang penting sebagai "prestasi ganda", yaitu prestasi Islam dan bahasa Arab. Karena itu, banyak penulis yang kemudian menyandingkan kata "Islam dan Arab" dalam berbagai judul karya, seperti al-Wâ $\hat{\imath} \hat{\imath}$ Târîkh al-'Ulûm 'inda al-'Arab karya 'Abduh al-Hilwu dan Bahzad Jâbir, Târikh al-Falsafah al'Arabiyyah karya Jamîl Shalîba, Tajalliyât al-Falsafah al-'Arabiyyah karya AbûYa'rib alMarzûqî, dan sebagainya.

Prestasi tersebut disebabkan oleh empat faktor. Di antaranya adalah faktor politik, yaitu adanya political will dari penguasa yang sangat haus dan antusias terhadap pengembangan iptek saat itu untuk mengembangkan beberapa tradisi ilmiah dan sistem pendidikan yang berorientasi kepada intelektualiasi sekaligus spiritualisasi. Ke-dua, faktor ekonomi berupa kemakmuran dan kesejahteraan rakyat di bidang ekonomi, sehingga sebagian besar dari mereka menekuni bidang keilmuan secara "khusyuk": serius dan produktif. Ketiga, faktor bahasa Arab yang memang sangat akomodatif untuk dijadikan sebagai media reproduksi pemikiran dan karya-karya ilmiah para ilosof dan ilmuwan Muslim. Meskipun al-Khalîl ibn Ahmad, Sîbawaih, Ibn Sînâ, al-Fârâbî, al-Râzî, Ibn Miskawaih, al-Ghazâlî, Ibn Rusyd, Ibn Mâlik dan sebagainya bukan orang Arab asli, mereka dengan penuh ekspresi dan apresiasi menjadikan bahasa Arab sebagai bahasa ilmu. Madrasah Nizhamiyyah di Persia, tempat alGhazâlîdigurubesar-kan, Madrasah al-Ayyubiyyah, Pusat-pusat Studi di Harran dan Jundisyapur (Persia) serta al-Azhar di Kairo juga menjadikan bahas Arab sebagai bahasa akademik: bahasa studi, pendidikan, dan kebudayaan mereka. Keempat, faktor ideologi dan mazhab teologi negara yang rasional (Mu'tazilah) juga turut mendinamisasikan pengembangan ilmu dan peradaban. Istana pada masa itu bukan sekadar singgasana, tetapi sekaligus menjadi pusat diskusi, perdebatan akademik, dan sebagainya.

Posisi strategis bahasa Arab sebagai bahasa pendidikan, kebudayaan, politik dan sebagainya dalam kehidupan sehari-hari pada masa kejayaan Islam tersebut, tidak dapat dipisahkan dari beberapa faktor penting. Di antaranya: pertama, faktor ideologis; bahwa bahasa Arab memang sudah "mengkristal" dengan agama Islam yang dianut oleh 
pemeluknya. Kedua, faktor doktrinal; bahwa al-Qur'an yang berbahasa Arab itu sangat menekankan umatnya mencari dan mengembangkan ilmu pengetahuan sehingga umat Islam terpacu untuk memahami dan mengaktualisasi-kan ajaran Islam yang tertuang dalam teks Arab al-Qur'an dan al-Sunnah. Ketiga, faktor linguistik; bahwa bahasa Arab-hingga kinitetap memperlihatkan sebagai bahasa fushhâ yang berkembang dinamis, sanggup mengikuti perkembangan zaman disebabkan oleh berbagai keunggulan morfologis, sintaksis, semantik dan so-siologis. Keempat, faktor politik; dukungan penguasa dan rakyat yang multilateral dan multi-etnis dari Andalusia (Spanyol) di Barat dan Persia di Timur memungkinkan bahasa Arab berkembang dan tersosialisasi dengan sangat efektif dalam berbagai lapisan masyarakat. Ekspansi politik Islam, terutama pada masa 'Umayyah dan Abbâsiyah tampak berimplikasi pada proses Islamisasi serta arabisasi bahasa. Penguasa, ulama, dan partisipasi publik yang plural dan multikultural dalam pengembangan sistem pendidikan Islam membuat kemajuan ilmu pengetahuan dan peradaban Islam menjadi semakin progresif.

\section{Aktualisasi Peran Bahasa Arab dalam Pengembangan Ilmu dan Peradaban}

Dari uraian-uraian yang pernah ada dapat ditegaskan bahwa warisan intelektual Yunani, khusus-nya di bidang ffilsafat yang cukup kaya dan subur itu, ternyata banyak menarik perhatian umat Islam, terutama para mutakallimûn (teolog) yang banyak dihadapkan kepada perdebatan teologis dan kebutuhan untuk menggunakan logika dan filsafat dalam berargumentasi. Khazanah Hellenistik yang pernah dominan cukup lama di berbagai wilayah Asia Barat, Asia Kecil, dan sebagian Afrika mulai menggugah para ilmuwan Islam untuk mengenal dan mempelajarinya. Pengaruh Hellenisasi telah dimulai pada masa pertengahan dinasti Umayyah dan puncaknya pada masa Abbasiyah. Pengaruh tersebut tampak pada pendirian Pusat Observatori Astronomi di Damaskus, Suriah sekitar 700 M. Dengan kata lain,

cikal bakal tradisi ilmiah dan penerjemahan karya-karya dari berbagai bahasa asing ke dalam bahasa Arab mulai berkembang pada masa Bani Umayyah.

Puncak kemajuan ilmu pengetahuan dan peradaban Islam terjadi pada masa pemerintahan Bani 'Abbâsiyah. Sejarah mencatat bahwa salah satu faktor penting keberhasilan pengembangan peradaban saat itu adalah karena berkembangnya gerakan penerjemahan (arabisasi) yang dimotori oleh elit penguasa, yaitu Hârun al-Rasyîd (786-809 M) dan al-Makmun (786-833 M). Gerakan penerjemahan itu disosialisasikan dengan ditunjang oleh adanya pusat riset dan pendidikan seperti Bait al- $\underline{H i k m a h ~ d a n ~ D a ̂ r ~ a l-~}$ $\underline{H}$ ikmah. Penerjemahan karya-karya asing tidak terbatas pada ilmu-ilmu dasar, filsafat Yunani, melainkan juga mencakup matematika, astronomi, isika, geometeri, optika, musik, dan kedokteran yang berasal dari bahasa Suryani, Persia dan India.

Gerakan penerjemahan karya-karya ilmiah berbahasa asing ke dalam ba-hasa Arab tersebut, selain mendorong pengembangan ilmu pengetahuan dan teknologi, juga berpengaruh besar terhadap wacana keilmuan Islam, baik ilmu-ilmu tradisional maupun ilmu-ilmu rasional, sehingga umat Islam tidak hanya bertindak sebagai pengalih ilmu tetapi juga sebagai penyusun, pengembang, dan pembangun berbagai disiplin ilmu pengetahuan baru. Dalam konteks ini, setidaknya ada tiga tahapan perkembangan peradaban Islam. 
Pertama, munculnya gerakan penerjemahan dan pemahaman berbagai karya asing ke dalam bahasa Arab. Kedua, implikasi dari gerakan ini, adalah lahirnya fase kreasi ilmu (marhalah al-ibdâ ${ }^{`}$ al-'ilmî). Bangsa Arab (Muslim) tidak lagi sekadar menerjemah-kan tetapi juga memproduksi: menulis dan mengembangkan ilmu melalui berbagai

penelitian dan pengembangan. Ketiga, berkembangnya fase inovasi dan aplikasi ilmu pengetahuan (marhalah al-ibtikâr wa al-tathbîq al-'ilmî) sehingga melahirkan ke-majuan teknologi dan karya-karya seni dan budaya. Ilmu dalam Islam ditransformasikan dan dikontekstualisasikan dengan ke-hidupan nyata. ${ }^{30}$ Semua tahapan dan fase perkembangan itu tidak terlepas dari peran bahasa Arab sebagai bahasa ilmu dan teknologi.

Ketika peradaban Islam di Spanyol dan Sicilia mengalami kemajuan, terutama di bawah pengaruh Ibn Rusyd (1126-1198 M), Barat masih terlelap dalam kegelapan ilmu. Setelah menyadari ketertidurannya, Barat lalu bangkit, kemudian melakukan gerakan penerjemahan seperti pernah dilakukan oleh umat Islam. Pengaruh Averoisme di Barat ternyata membawa mereka bangkit dari ketertinggalannya, sehingga mereka berhasil mencapai renaisance (tanwîr wa nahdhah), dengan revolusi industri sebagai titik awalnya. Demikian pula restorasi dan reformasi di Jepang setelah kalah dalam Perang Dunia II juga dimulai dengan gerakan penerjemahan besar-besaran ter-hadap karya-karya ilmuwan Barat dari bahasa Inggris ke dalam bahasa Jepang. Jadi, penerjemahan, baik sebagai ilmu maupun praktik atau profesi, mempunyai kontribusi yang besar dalam pengembangan ilmu pengetahuan, pendidikan dan peradaban umat manusia sepanjang sejarah. Pe-radaban Islam Indonesia modern, kalau boleh disebut seperti itu, tampaknya belum melalui tahapan perkembangan dan pengembangan ilmu yang pernah dilalui oleh umat Islam di masa lalu ketika hendak mencapai puncak kejayaannya.

Setelah Bagdad jatuh pada tahun $1258 \mathrm{M}$ akibat dihancurkan oleh tentara Mongol, dan dunia Islam mengalami kemunduran, posisi bahasa Arab pun mengalami pergeseran dari bahasa akademik-ilmiah menjadi bahasa yang cenderung lebih bernuansa religius (bahasa agama, bahasa spritual). Karya-karya intelektual dalam berbagai bidang tidak begitu banyak lagi ditemukan dalam bahasa Arab. Bahasa Arab seakan menjadi "loyo" karena ketidak keberdayaan politik dan ekonomi umat Islam vis a vis hegemoni Barat yang maju secara sains dan ekonomi. Perhatian umat Islam pada saat itu cenderung ditujukan kepada perebutan kekuasaan di satu pihak, dan di pihak lain, sebagian cenderung memilih lelaku su istik atau " "asyîq-ma'syûq" bertarekat, atau lebih mementingkan urusan ukhrawi dengan "berdzikir" daripada mengembangkan ilmu pengatahuan dan peradaban.

Meskipun demikian, menarik dicatat bahwa dalam abad ke-18 dan 19, beberapa ulama Jawi, seperti Syekh Nawawi al-Bantani, Syekh Mahfuzh al-Tirmasi, Syekh Ahmad Khatib alMinangkabawi, Syekh Syamsuddin al-Sumatrani dan sebagainya, yang bermukim di Haramayn (Mekkah dan Madinah), termasuk KH. Hasyim Asy'ari, banyak menelurkan karya-karya bermutu yang ditulis dalam bahasa Arab. Setelah masa "keemasan ulama Jawi" tersebut, karya-karya ulama Indonesia yang ditulis dalam bahasa Arab mengalami penurunan. $^{31}$ Hal ini menunjukkan bahwa aktualisasi peran bahasa Arab dalam pengembangan ilmu dan peradaban perlu direvitalisasi dan dikembangkan di era modern ini.

Menurut penulis, ada sejumlah faktor yang menjadi penyebab "kemandulan akademik" dalam berkarya dengan menggunakan bahasa Arab. Di antaranya adalah ketidakmampuan 
sebagian ulama dalam mengekspresikan karya mereka dengan bahasa Arab (karena mungkin bahasa Arab dinilai sulit dan berbelit-belit), penghargaan terhadap karya ilmiah berbahasa Arab tergolong minim, tradisi dan kondisi ilmiah tidak kondusif, sistem pendidikan dan pengajaran bahasa Arab di berbagai institusi pendidikan Islam kurang menunjang, dan rendahkan kesadaran "promosi" karya intelektual anak bangsa ini ke dunia Arab; bahkan di kalangan bangsa-bangsa Arab sendiri terdapat ke-cenderungan yang menguat terhadap penggunaan bahasa Arab 'âmiyyah (pasaran, bukan bahasa formal) belakangan ini.

Fakta-fakta historis dan sosial intelek-tual yang diuraikan di atas memperlihatkan kepada kita bahwa bahasa Arab pada awal Islam hingga puncak kemajuan ilmu pengetahuan dan peradaban Islam memainkan setidak-tidaknya lima peran penting. Pertama, bahasa Arab berperan sebagai bahasa integrasi. Sejarah menun-jukkan bahwa mayoritas bangsa-bangsa yang ditaklukkan Islam semula bukan berbahasa Arab. Akan tetapi, dalam perkembangannya warga masyarakat yang baru dibebaskan oleh penguasa Islam ini, bahasa Arab mampu menyatukan banyak suku bangsa dan budaya. Peran integrasi ini menjadi semakin solid dan kuat terutama setelah khalifah Abdul Malik ibn Marwan melakukan gerakan arabisasi dan menjadi bahasa Arab sebagai bahasa negara dan administrasi pemerintahan. Peran integratif bahasa Arab ini ditopang oleh ajaran Islam yang mengedepan integrasi dan kesatuan akidah, kesatuan ukhuwah, kesatuan akhlak, kesatuan pemikiran, kesatuan hukum, dan kesatuan budaya. Kedua, bahasa Arab berperan sebagai bahasa konservasi. Ketika Islam ber-kembang ke luar Jazirah Arabia, kebutuhan umat Islam untuk dapat mengakses dan memahami sumber ajaran Islam (al-Qur'an) tentu semakin mendesak. Pada saat sama, ketika sebagian umat Islam non-Arab banyak melakukan lahn, para ulama bahasa Arab merasa perlu merumuskan ilmu-ilmu dasar bahasa Arab (nahwu dan sharaf). Dengan diformulasikannya ilmu ini, bahasa Arab tidak hanya berperan menjaga kelestarian (konservasi) kekayaaan bahasa dan budaya Arab itu sendiri dari masa ke masa, termasuk konservasi turats (warisan atau khazanah intelektual Arab dan Islam), tetapi juga menjaga otentisitas al-Qur'an. Karena itu, formulasi ilmu tersebut juga dibarengi dengan pemberian tanda baca (titik-titik) dan harakat (fathah, dhammah, kasrah, dan sukûn) al-Qur'an. Jadi, terdapat hubungan simbiosis-mutualisme ('alâqah mutabâdilah wa mutalâzimah) antara Islam dan bahasa Arab, antara agama dan bahasa, atau antara doktrin dan media komunikasi sehingga kedua berkembang secara saling mendukung. Tanpa spirit Islam yang mengharuskan umatnya cerdas dalam "iqra", mustahil bahasa Arab berkembang maju. Ketiga, bahasa Arab berperan sebagai bahasa edukasi dan studi. Ketika Islam mencapai kemajuannya, bahasa Arab kemudian memainkan peran se-bagai bahasa pendidikan, pembelajaran dan penelitian ilmiah di hampir semua lapisan masyarakat Arab sehingga ba-hasa Arab kemudian menjadi bahasa ilmu pengetahuan dan teknologi. Hal ini ditunjang oleh kontribusi kebijakan politik dan inansial yang sangat besar dari elit penguasa, terutama al-Makmun, kepada para peneliti dan pengembang ilmu. Sedemikian besar dukungan kekuasan terhadap penerjemahan, penelitian, dan pengembangan ilmu, alMakmun yang mempercayakan pengembangan lembaga riset Bait al- $\underline{H}$ ikmah kepada Hunain ibn Ishâq menilai karya hasil terjemahannya dari bahasa Yunani dan Suryani ke dalam bahasa Arab itu dengan insentif berupa emas seberat hasil karya terjemahannya. Artinya, jika dia berhasil menerjemahan karya asing ke dalam bahasa Arab seberat $1 \mathrm{~kg}$, 
maka insentifnya pun berupa $1 \mathrm{~kg}$ emas. Dalam waktu bersamaan, berbagai lembaga pendidikan yang sudah berkembang di wilayah-wilayah Islam seperti madrasah Jundisapur, Herat, Harran, Iskandaria, Antakia, dan sebagainya menjadikan bahasa Arab sebagai bahasa edukasi dan studi, bahasa penelitian, dan pengembangan ilmu. Bahkan, menurut Ira M. Lapidus, budaya (kultur) bahasa Arab merupakan produk dari tiga hal, yaitu produk masyarakat perkotaan kelas menengah yang konsen dengan keilmuan Islam, produk loyalitas kesukuan bangsa Arab, dan produk penguasa (istana). Keempat, bahasa Arab berperan sebagai bahasa komunikasi lintas suku bangsa dan generasi yang mempercepat proses transmisi nilai-nilai Islam dan nilai-nilai sosial kemanusiaan di kalangan masyarakat Arab. Seperti karakter bangsa Arab pada umumnya, bahasa Arab merupakan bahasa yang terbuka. Sebagai bahasa terbuka, bahasa Arab sejak awal memperlihatkan kemampuannya beradaptasi dan menerima perubahan, termasuk mengadopsi bahasa-bahasa Asing. Dalam al-Qur'an, dapat dijumpai sejumlah kata yang berasal dari bahasa lain, seperti: irdaus, zanzabîl, kafûr, istibrâq, qamtharîr, salsabîl, dan sebagainya. Di era modern ini, bahasa Arab juga memperlihatkan perannya sebagai bahasa komunikasi dalam berbagai bidang, terutama politik, ekonomi, dan sosial budaya, termasuk media massa, baik di dunia nyata maupun dunia maya. Selain itu, sebagai bahasa komunikasi akademik, terutama di kalangan akademisi Arab, banyak sekali karya ilmiah dipublikasikan melalui berbagai media, juga menjadikan bahasa ini semakin berkembang, antara lain, dengan banyaknya mufradat dan istilah baru dalam bahasa Arab. Kelima, bahasa Arab berperan sebagai bahasa standarisasi di bidang ilmu-ilmu keislaman dan lainnya. Hal ini terbukti dengan dirintiskan penulisan kamus bahasa Arab. Menurut catatan sejarah, mu 'jam al-'Ain karya al-Khalil ibn Ahmad $(100-170 \mathrm{H})$ adalah kamus pertama di dunia Islam. Kamus ini sudah memiliki sistem dan metode ilmiah yang cukup solid. Dari kamus ini, kelak menginspirasi lahirnya aneka kamus dalam bahasa Arab, seperti Maqâyîs al-Lughah karya Ibn Faris, Lîsan al- 'Arab karya Ibn Manzhur, hingga aneka kamus istilah dalam berbagai bidang keilmuan yang, terutama, diprakarsai dan dikembangkan oleh Maktabah Lubnan di Beirut.

Spesialisasi kamus dalam bahasa Arab mulai berkembang sejak tahun 1970-an, setelah beberapa negara di Timur Tengah mulai banyak bergumul dengan [atau terpengaruh oleh dinamika leksikologi] Barat, utamanya dalam rangka studi dan eksplorasi minyak, sehingga proses transformasi teknologi pun terjadi dan dengan sendirinya usaha untuk melakukan "Arabisasi” istilah-istilah teknologi pun berkembang. Spesialisasi itu, antara lain, terlihat pada terbitnya beberapa kamus sebagai berikut:

- Ahmad Syafî̀ al-Khathîb, Mu 'jam al-Mushthalahât al-'Ilmiyyah wa al-Fanniyah wa al-Handasiyyah, Beirût: Maktabah Lubnân, Cet. I, 1971 (Cet. VI, 1991).

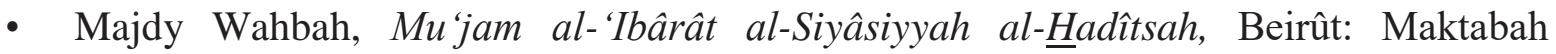
Lubnân, 1978.

- Ahmad Zaky Badawî, Mu'jam Mush-thalahât al-'Ulûm al-Ijtimâ'iyyah, Bairût: Maktabah Lubnân, 1982.

- Nabîh Ghattâs, Mu ‘jam Mushthalahât al-Iqtishâd wa al-Mâl wa Idârah al-A ‘mâl, Beirût: Maktabah Lubnân, 1985.

- Muhammad MushthafâZaidân, Mu jam al-Mushthalahâat al-Nafsiyyah wa alTarbawiyyah, Beirût: Dâr al-Syurûq, 1984. 
- Nabîh Ghattâs, et.al., Mu 'jam al-Idârah,

Beirût: Maktabah Lubnân, 1983.

- Muhammad 'Alîal-Khûlî, Mu'jam 'Ilm al-Lughah al-Tathbîqî, Beirût: Maktabah Lubnân, 1986.

- Hârits Sulaimân al-Fâruqî, al-Mu jam al-Qanunî, Beirût: Maktabah Lubnân, Edisi III, 1991.

- Jamîl Shalîbâ, al-Mu 'jam al-Falsa î, dua jilid, Beirût: Dâr al-Kitâb al-Lubnânî, 1982.

- Sumûhî Fawqa al-'Adah, Mu'jam al-Diblumâsiyyah wa al-Syu'ûn al-Dawliyyah, Beirût: Maktabah Lubnân, tt.

Agar kelima peran bahasa Arab dapat diaktualisasikan, menurut penulis, perlu adanya terobosan-terobosan inovatif baik dalam "pengilmuan" bahasa Arab maupun pembelajarannya. Misalnya saja, orientasi pembelajaran bahasa Arab perlu diubah, terutama di dalam sistem pendidikan pesantren dan madrasah (kemudian di perguruan tinggi), dari sekadar sebagai proses spiritualisasi atau untuk membaca "kitab kuning" menjadi proses intelektualisasi dan profesionalisasi. Bahasa Arab tidak sekadar diposisikan sebagai alat untuk memahami melainkan juga media untuk komunikasi, reproduksi keilmuan, dan diplomasi kebudayaan. Strateginya adalah dengan pendekatan politik dan akademik.

Dalam konteks itu, kita harus bisa meyakinkan pemerintah, utamanya Kementerian Agama dan Kementerian Pendidikan dan Kebudayaan agar mendeklarasikan dan memberikan maklumat moral bahwa bahasa Arab itu sangat penting dan perlu dipelajari, baik oleh umat Islam maupun yang lain. Dengan begitu, bahasa Arab bukan lagi "bahasa milik orang Islam" dan hanya dikaji di lembaga-lembaga pendidikan Islam. Aneka kegiatan diplomasi dan promosi (pariwisata, peluang investasi, kerjasama ekonomi, dan sebagainya) dengan berbagai negara Timur Tengah perlu didorong sedemikian rupa sehingga posisi tawar bahasa Arab di Indonesia semakin kuat dan menarik minat banyak kalangan.

Selain itu, kesadaran umat Islam juga harus dibangkitkan, melalui berbagai lembaga pendidikan dan media massa bahwa belajar bahasa Arab itu tidak sekadar untuk memahami Islam, melainkan juga untuk memahami ilmu pengetahuan, yang kini sudah mulai banyak ditulis dalam bahasa Arab.

Selanjutnya, perlu dipikirkan bersama adanya upaya pencitraan dan sosialisasi bahwa bahasa Arab itu penting dikaji dan dikuasai sebagai bahasa studi Islam dan ilmu pengetahuan. Diperlukan juga upaya standarisasi kemampuan bahasa Arab bagi calon mahasiswa maupun calon lulusan Perguruan Tinggi (misalnya dengan TOAFL), sehingga mereka memiliki standar kompetensi dalam berbahasa Arab. Penciptaan lingkungan berbahasa Arab (dengan keteladanan dosen dalam berbahasa Arab sebagai bahasa akademik/ perkuliahan) penting digalakkan. Para dosen juga perlu membiasakan menulis karya ilmiah dalam bahasa Arab, sehingga dikenal oleh dunia luar, khususnya dunia Arab. Pemanfaatan teknologi informasi dan komunikasi yang canggih, khususnya dalam bidang teknologi dan multimedia pendidikan bahasa Arab juga perlu dipikirkan bersama. Intinya: aktualisasi peran bahasa Arab harus dibarengi dengan reformasi sistem pendidikan bahasa Arab secara terpadu, integral dan berkelanjutan, mulai dari tingkat dasar, menengah hingga perguruan tinggi. Dengan demikian, bahasa Arab insya Allah akan menjadi bahasa yang menarik, terutama dalam posisinya sebagai bahasa pendidikan dan kebudayaan. Umat Islam, baik kalangan santri 
maupun non-santri, dipandang perlu memberikan apresiasi yang memadai terhadap pengembangan dan sosialisasi bahasa Arab di Indonesia.

Apresiasi yang antara lain perlu diaktualisasikan adalah intensifikasi dan ekstensifikasi jam belajar bahasa Arab di madrasah-madrasah maupun sekolah-sekolah, bahkan perguruan tinggi Islam seperti UIN, IAIN, STAIN, Perguruan Tinggi Negeri di bawah naungan Kemendikbud dan PTAIS lainnya. Berbagai institusi pendidikan dan lembaga pemerintahan lainnya, seperti Akademi Pariwisata, Akademi Seni dan Budaya, Departemen Pariwisata dan Budaya, Departemen Luar Negeri dan sebagainya sudah saatnya "melirik" pangsa pasar negara-negara Arab yang secara ideologis dan religius memiliki kesamaan dengan bangsa kita yang mayoritas beragama Islam, dan secara ekonomis, mereka lebih potensial dan kaya. Promosi dan diplomasi kebudayaan ke berbagai negara Timur Tengah tampaknya masih minim. Karena itu, intensifikasi kerjasama antarnegara dan perwakilan Indonesia di Timur Tengah perlu dikembangkan dan dioptimalisasikan.

\section{Tantangan dan Prospek Bahasa Arab ke Depan}

Peristiwa Selasa kelabu, 11 September 2001 tampaknya banyak membawa berkah bagi umat Islam. Meski label "teroris" kerapkali dialamatkan Barat kepada umat Islam, para peminat kajian Islam di Barat, khususnya Amerika Serikat, semakin meningkat. Rasa keingintahuan mereka tentang Islam-berikut upaya pembuktian benar tidaknya Islam sebagai agama yang menyokong terorisme-setidaknya mengantarkan mereka untuk mengkaji sumber ajaran Islam, yaitu al-Qur'an dan al-Sunnah, yang pada gilirannya mendorong mereka mempelajari bahasa Arab.

Sebelum peristiwa tersebut, memang bahasa Arab sudah dipelajari di berbagai universitas terkemua di Barat, seperti di Canada, Amerika Serikat, Perancis, Inggris, dan Jerman. Bahasa Arab dikaji sebagai mata kuliah wajib bagi mereka yang melakukan studi Islam. Dalam pandangan mereka, mustahil melakukan studi Islam tanpa mempelajari bahasa Arab.

Menurut al-Munazhzhamah al-Islâmîy-yah li al-Tarbiyah wa al- 'Ulûm wa al-Tsaqâfah (organisasi Islam untuk Pen-didikan, Ilmu Pengetahuan, dan Kebu-dayaan) yang berpusat di Rabat, Marokko, ada tiga tantangan dan poros yang dapat membuat bahasa Arab di masa depan

leading (tetap eksis dan berdaya). Pertama adalah merancang dan memformulasikan kurikulum pendidikan dan penyusunan buku ajar bahasa Arab bagi non-Arab. Kedua adalah penyiapan dan pengkaderan guru-guru/dosen-dosen/pakar-pakar bahasa Arab dan guru-guru pendidikan Islam serta penyelenggaraan berbagai pelatihan yang efektif untuk mereka. Ketiga adalah penulisan bahasa-bahasa bangsa Muslim dengan huruf-huruf Arab. ${ }^{38}$

Selain hal tersebut, upaya lain yang perlu disosialisasikan dalam rangka menjadikan bahasa Arab sebagai bahasa pendidikan dan kebudayaan, bahasa ilmu pengetahuan, dan peradaban adalah promosi dan diplomasi kebudayaan ke berbagai negara di Timur Tengah, agar para turis dan wisatawan yang berkunjung ke Indonesia meningkat. Seiring dengan itu, bahasa Arab juga layak dimasukkan dalam kurikulum akademi pariwisata atau lembaga pendidikan lainnya yang beorientasi memberikan jasa kepariwisataan dan perhotelan. Dengan begitu, kita dapat memberikan pelayanan yang lebih baik, dan pada gilirannya, 
dengan semakin banyak turis atau investor dari Timur Tengah ke Indonesia, niscaya sosialisasi bahasa Arab di kalangan masyarakat Indonesia lebih mudah dan efektif.

Dalam konteks tersebut, perlu juga dipikirkan bersama kemungkinan di-jadikan bahasa Arab sebagai salah satu bahasa siaran berita pada TVRI dan TV-TV swasta lainnya. Penyiaran berita dengan bahasa Arab melalui TV dan radio, - meski masih terbatas pada Radio at-Tahiriyah - diharapkan dapat memberi nuansa baru bagi umat Islam Indonesia. Beberapa

tahun lalu, bahasa Arab memang sudah menjadi salah satu acara rutin (pelajaran Bahasa Arab) di TVRI dan TPI, namun - barangkali karena faktor marketabilitas dan rating yang tidak komersial - acara itu akhirnya ditiadakan sehingga bahasa Arab kehilangan tempat. Di bulan Ramadhan lalu, alhamdulillah, ada tayangan serial dalam bahasa Arab tentang sejarah Islam, khususnya Umar ibn al-Khaththab di Trans7 dan belakangan juga ada siaran langsung TV al-Jazeerah yang diterjemahkan ke dalam bahasa Indonesia yang disiarkan oleh TVOne. Seiring dengan banyak media berbahasa Arab, terutama di dunia maya, sudah saatnya juga dikembangkan bahan ajar dan sumber belajar berbasis ICT yang dipandang dapat menunjang proses pembelajaran bahasa Arab yang komunikatif dan interaktif: pembelajaran bahasa Arab yang membisakan dan membiasakan, bukan membisukan dan membosankan!

\section{Karakteristik Peradaban Islam}

Bahasa Arab akan tetap menjadi bahasa umat Islam yang memungkinkan "dilahirkan kembali" peradaban Islam modern. Tentu saja, kita harus berjuang sekuat tenaga untuk melahirkannya. Islam mempunyai potensi dan sumber daya nilai yang luar biasa unggul untuk mewujudkan peradaban dimaksud. Jika dibandingkan dangan peradaban Barat yang sekuler dan materialistik, peradaban Islam mempunyai beberapa karakteristik yang perlu dijadikan sebagai visi, misi, orientasi, dan aktualisasi pengembangan sains dan teknologi Islami ke depan. Karakteristik peradaban dimaksud adalah sebagai berikut.

Pertama, peradaban Islam itu bersifat rabbânî, bersumber dari dan bermuara kepada tata nilai ketuhanan. Sumber utamanya adalah wahyu, yaitu: al-Qur'an dan al-Sunnah. ${ }^{39}$ Orientasi peradaban Islam juga mengarah kepada nilai-nilai transendental, tidak hanya berupa mewujudkan $\hat{\imath}$ al-dunya hasanah, tetapi juga $\hat{\imath}$ al-âkhirati hasanah sekaligus waqinâ adzâba al-nâr (QS al-Baqarah [2]: 201). Peradaban Islam juga harus memposisi-kan kehidupan dunia sebagai instrumen atau sarana menuju kebahagiaan hidup di akhirat. Karena itu, pemikiran Islam tidak seharusnya berorientasi kekinian dan

kedisinian semata, tetapi harus berorientasi jauh ke depan. Allah Swt. ber irman: Walalâkhiratu khairul laka minal ûla. Artinya: Orientasi kehidupan masa depan [akhirat] itu sungguh lebih baik daripada orientasi masa kini [kehidupan dunia] (QS al-Dhuha [93]: 4).

Selain itu, peradaban Islam dibangun di atas fondasi tauhid (ajaran tentang keesaan Allah, kesatuan wujud, kesatuan penciptaan, kesatuan kemanusiaan, kesatuan tujuan). Kesatuan akidah inilah yang merupakan pemersatu (uniting factor) berbagai upa-ya pemikiran menuju kamajuan dan kese-jahteraan umat. Penelitian serius yang dilakukan oleh pemikir Muslim dalam rangka mengungkap rahasia dan hukum-hukum alam tidak lain karena 
didasari oleh semangat dedikasi atau pengabdian hanya untuk memperoleh ridha (perkenan, restu) Allah Swt. dan sekaligus untuk mengokoh iman yang ada dalam diri pemikir dan siapa saja yang membaca dan memahami pemikirannya. ${ }^{40}$

Kedua, peradaban Islam bersifat insâniyyah (kemanusiaan). Produk pe-radaban Islam hendaknya berorientasi

kepada proses humanisasi, pemanusiaan manusia, dengan mengedepankan ke-maslahatan manusia. Karena itu, peradaban Islam memperioritaskan pemberlakuan rambu-rambu dan nilai-nilai moral yang luhur dalam berinteraksi dengan kitab suci maupun dalam mengembangkan wacana keilmuan. Peradaban Islam dalam berbagai bidang tidak berwujud teori-teori yang tidak membumi, melainkan seharunya melahirkan tatanan kehidupan masyarakat yang lebih beradab, adil, dan sejahtera. ${ }^{41}$ Dengan kata lain, peradaban Islam harus mampu melayani kepentingan dan kemaslahatan manusia sesuai dengan norma-norma syariah dan nilai-nilai akhlâq karîmah.

Ketiga, peradaban Islam itu bersifat syumûliyyah, komprehensif dan terpadu, meliputi segala bidang keilmuan, keterampilan, berorientasi dunia-akhirat. Pemikiran Islam tidak terbatas mengkaji masalah meta isika - seperti yang digeluti oleh ilosof dan teolog - tetapi juga menca-kup seluruh bidang dan aspek kehidupan manusia. Komprehensivitas peradaban Islam juga tidak terletak pada tema kajian tetapi juga meliputi sumber pengetahuan. Sumber pengetahuan dalam pemikiran Islam tidak terbatas pada logika, rasio [rasionalisme] dan pengalaman empiris [empirisme] tetapi juga bersumber dari wahyu dan intuisi [gnostik, ma'rifah]. ${ }^{42}$ Demikian pula, metode yang digunakan dalam memproduksi pemikiran tidaklah semata-mata deduksi-induksi tetapi juga merupakan perpaduan antara ta'aqqulita 'ammuli, (penalaran logis dan kontemplatif), bayânî (penjelasan elaboratif), burhânî (demonstratif), jadalî (dialektik) dan hadasî (intuitif). ${ }^{43}$ Pemikiran rasional tidak cukup untuk memahami realitas meta isika dan isika. Pengetahuan gnostik (ma'rifah) atau pendekatan su istik, seperti yang pernah ditempuh oleh al-Ghazzali (w. 1111) juga dapat mengantarkan dirinya menuju mukâsyafah (penyingkapan tabir Ilahi) dan ma 'rifatullâh.

Keempat, peradaban Islam itu bersifat al-hada iyyah al-sâmiyah (bercita-cita dan bertujuan luhur). Pemikiran Islam tidak menganut paham "pemikiran untuk pemikiran atau ilmu untuk ilmu" tetapi

dimaksudkan untuk merealisasikan cita-cita mulia dan luhur, yaitu: dedikasi manusia kepada Allah Swt. Karena itu, pemikiran Islam menghendaki aksi dan implementasi. Pemikiran, ilmu, gerakan, dan amal merupakan satu kesatuan menuju kebaikan dan kesalehan sosial. Keluhuran tujuan pemikiran Islam juga terletak pada kesadaran pemikirnya terhadap tuntutan realitas dan petunjuk syariah. ${ }^{44} \mathrm{Jadi}$, pemikiran Islam bukan semata-mata retorika wacana tanpa makna dan fakta.

Hanya saja, ketika wacana pemikiran Islam itu hendak diaplikasikan dalam realitas empirik, visi dan cita-cita luhur pemikiran Islam terkadang mengalami disorientasi dan distorsi. Gerakan pe-mikiran "sala isme", misalnya, yang mencoba mengembalikan persoalan umat kepada igur dan model ulama salaf dalam memahami dan mengamalkan Islam, justru "terjebak" dengan realitas historis masa lalu yang aktualisasinya tidak cukup aktual dan relevan dengan persoalan masa kini. Demikian pula, "Pemikiran Islam Liberal" 
yang disuarakan oleh intelektual muda melalui Jaringan Islam Liberal (JIL) terkesan agak kebablasan dalam memahami

ajaran Islam, sehingga nilai-nilai dasar yang diperjuangkan lebih "kebarat-baratan" daripada keislaman.

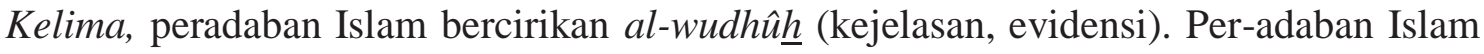
itu jelas tidak hanya dari segi sumber dan metode tetapi juga jelas dari segi orientasi, kerangka kerja dan implementasinya. Peradaban Islam tidak bertolak dari mitos dan khayalan. Pemikiran Islam bersumber dari dan berinteraksi dengan ajaran Tuhan untuk diaktualisasikan dalam kehidupan nyata. Peradaban Islam seharusnya juga jelas dimaksudkan untuk memenuhi itrah dan kebutuhan manusia, dan bukan untuk mengabdi kepada rejim dan kekuasaan. ${ }^{45}$ Selain itu, peradaban Islam juga memiliki kejelasan asalusul, akar-akar historis, dan peta kajian, sehingga mampu memberikan solusi terhadap permasalahan yang sedang terjadi. Ketika bangsa ini memerlukan pemecahan terhadap perosalan "korupsi berjamaah", pemikiran Islam seharusnya dapat merespons dengan solusi yang tidak hanya teori-teori akademik, tetapi juga dibarengi langkah-langkah konkret dalam upaya pemberantasannya.

\section{Simpulan}

Dari uraian terdahulu, dapat disimpul-kan bahwa peran bahasa Arab sebagai bahasa agama, bahasa integrasi dunia Arab (dan Islam), dan bahasa resmi PBB, tetap penting, tidak hanya dalam pengembangan kajian keislaman tetapi juga dalam pengem-bangan ilmu pengetahuan dan peradaban. Bahasa Arab dan peradaban Islam sepan-jang sejarahnya tidak dapat dipisahkan, bagaikan dua sisi dari mata uang. Di satu sisi bahasa Arab bisa berkembang maju karena al-Qur'an, dan di sisi lain, bahasa Arab perlu dikembangkan sebagai ilmu

karena dibutuhkan untuk melayani kajian al-Qur'an. Bahkan para qurrâ' adalah juga para ahli bahasa. Ilmu-ilmu bahasa Arab dan keislaman bisa berkembang, antara lain, karena adanya inspirasi dan motivasi dari al-Qur'an yang berbahasa Arab.

Ketika Islam berkembang luas dan bersentuhan dengan peradaban lain, bahasa Arab berperan sebagai jembatan penghubung keilmuan melalui gerakan penerjemahan. Gerakan ini mendapat momentum yang tepat, tidak hanya dari kalangan ulama, tetapi juga dukungan politik dan inansial dari umara, sehingga sinergi kekuasaan dan pengetahuan menjelma menjadi sebuah kekuatan yang dahsyat dalam pengembangan ilmu pengetahuan dan peradaban Islam. Gerakan penerjamahan karya-karya Yunani, India, dan Persia ke dalam bahasa Arab, lalu ditindaklajuti dalam bentuk penelitian dan pengembangan karya-karya kreatif dan inovatif dari ulama Islam yang juga berkolaborasi dengan ilmuwan non-Muslim, mejadikan bahasa Arab sebagai bahasa ilmu dan peradaban.

Bahasa Arab ke depan diprediksi dapat berperan lebih optimal lagi jika lembaga pendidikan Islam dapat bersinergi dengan kekuasaan dalam memantapkan perannya sebagai bahasa diplomasi, bahasa edukasi, dan bahasa komunikasi dalam berbagai bidang. Karena itu, diperlukan adanya inovasi sistem pendidikan bahasa Arab yang lebih dari sekadar PAIKEM, misalnya pembelajaran bahasa Arab berbasis riset, berbasis budaya, berbasis penciptaan lingkungan berbahasa komunikatif dan produktif. Peran bahasa Arab sebagai bahasa edukasi 
dan studi, termasuk sebagai standarisasi, perlu diaktualisasikan dengan mendinamisasikan berbagai kegiatan akademik yang kreatif dan inovatif.

\section{Daftar Rujukan}

'Abd al-Wahhâb Ibrâhim AbûSulaimân, Kitâbât al-Bahts al- 'Ilmî wa Mashâdir al-Dirâsât al-Islâmiyyah, Beirut: Dâr al-Syurûq, 1978.

Abdul Wahab, Muhbib, "Revitalisasi dan Aktualisasi Bahasa Arab sebagai Bahasa

Pendidikan dan Kebudayaan”, dalam Jurnal Jauhar, Jakarta: Program Pascasarjana UIN Syarif Hidayatullah, Vol. 3, No. 1, 2002.

_ Epistemologi dan Metodologi Pembelajaran Bahasa Arab, Jakarta: UIN Jakarta Press, 2008.

al-Afghani, Sa id, Min Tarîkh al-Nahwwi, Beirut: Maktabah al-Falah, 1985.

Azra, Azyumardi, Jaringan Ulama, Bandung: Mizan, 1998.

Badrân, Muhammad Mamdûh, "al-Lughah al- 'Arabiyyah wa Tadrîsuhâli ghair al-Nâthiqîn bihâ", dalam Ta 'lim al-Lughah al- 'Arabiyyah li Ghair al-Nâthiqîn bihâ: Qadhâyâ wa Tajârib, Tunis: Isesco, 1992.

Bakalla, MH., Pengantar Penelitian Studi Bahasa Arab, Terj. dari Arabic Culture, Through Its Language and Literature oleh Males Sutiasumarga, Jakarta: Hardjuna Dwitunggal, 1984

al-Dâyah, Muhammad Ridhwân, al-Maktabah al-'Arabiyyah wa Manhâj al-Bahts, Damaskus: Dâr al-Fikr, 1999.

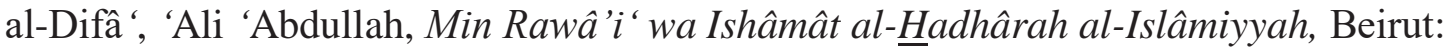

Muassasah al-Risâlah, 1999

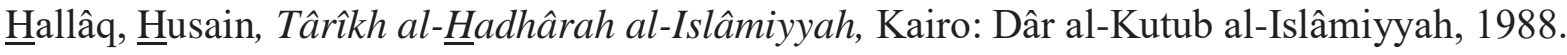

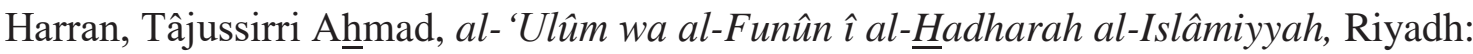

Dar Eshbekia, 2002.

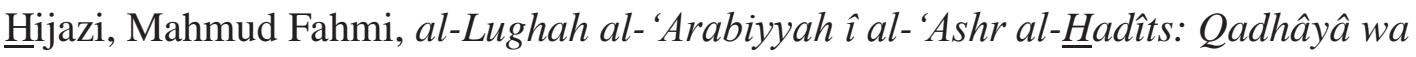
Musykilât, Kairo: Dar Quba', 1998.

al-Hilwu, 'Abduh, dan Bahzad Jabir, al-Wa î î Târîkh al- 'Ulûm 'inda al- 'Arab, Beirut: Dar al-Fikr al-Lubnani, 2002.

Ibn Fâris, al-Shâhibî ̂̂ Fiqh al-Lughah wa Sunan al- 'Arab î Kalâmihâ, Beirût: Mu'assasah Badrân, 1963.

Inânî, Mushthafâdan al-Iskandarî, al-Wasîth î Târîkh al-Adab al- 'Arabî, Kairo: Dâr alMa 'ârif, tt); dan

Ahmad Hasan al-Zayyât, Târîkh al-Adab al- 'Arabî, Beirut: Dâr al-Ma rifah, Cet. VII, 2001.

Isysy, Yûsuf, al-Dawlah al-Umawiyyah wa al-Ah

Mahhadat lahâ ibtidâ'ân min Fitnah 'Utsmân, Damaskus: Dâr al-Fikr, 1989.

al-Jâbiri, Muhammad 'Abid, Binyah al- 'Aql al- 'Arabi: Dirâsah Tahlîliyyah Naqdiyyah Li Nizhâm al-

Ma 'rifah î al-Tsaqâfah al- 'Arabiyyah, Beirut: Markaz Dirâsat al-Wahdah al'Arabiyyah, 1990. 
al-Kailânî, Mâjid 'Irsân, al-Fikr al-Tarbawî 'inda Ibn al-Taimiyah, Madinah: Maktabah alHâdi, 1986.

Lapidus, Ira M., Sejarah Sosial Umat Islam, terj: Ghufron M. Mas'adi Jakarta: Rajawali Press, 1999.

Ma'lûf, Louis, al-Munjid î al-Lughah wa al-A 'lâm, Beirut: Dâr al-Masyriq, 1986.

Madjid, Nurcholish, "Orientasi dan Metodologi Studi Islam Masa Depan”, dalam Jauhar, Jurnal PPs.

IAIN Jakarta, Edisi I, Desember 2000.

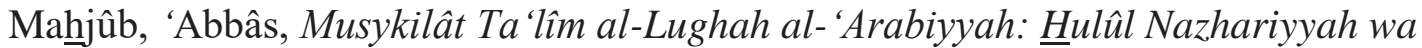
Tathbîqiyyah, Doha:

Dâr al-Tsaqâfah, 1986.

Mas'ud, Jibran, al- 'Arabiyyah al-Fush $\underline{h a: ~ S y a ' l a t u n ~ l a ~ t a n t h a ~ i ', ~ B e i r u t: ~ B a i t ~ a l-H i k m a h, ~}$ 2001.

Mukram, Abd al-'A 1 Sâlim, al-Lughah al- 'Arabiyyah i Rihâhb al-Qur'ân al-Karîm, Kairo:

'Alam al-Kutub, 1995.

Nakosteen, Mehdi, Kontribusi Islam atas Dunia Intelektual Barat, terjemahan, Surabaya:

Risalah Gusti, 1996.

Nawar, Fathullah, "al-Bu 'd al-Dînîmin Ta 'lîm al-Lughah al-'Arabiyyah li al-Nâthiqîna bi

Ghairihâ”, dalam Majallah al-Mujtama’ Edisi 1458, Juni 2001.

Qaddur, Ahmad Muhammad, Madkhal ilâ Fiqh al-Lughah al- 'Arabiyyah, Damaskus: Dar al-Fikr, 1999. Qadir, C.A., Ffilsafat dan Ilmu Pengetahuan dalam Islam, Terj. dari

Philosophy and Science in the Islamic

World oleh Hasan Basari, Jakarta: Obor Indonesia, 1989.

al-Qaradhâwî, Yûsuf, "Mustaqbal al-Lughah al-'Arabiyyah wa Tahaddiyatuhâ", diakses

dari http:// www.alriyadh.com /contents, 25-06-2003.

Qumaihah, Jabir, Atsar Wasâ'il al-I'lâm al-Maqrû 'ah wa al-Masmu'ah wa al-Mar'iyyah $\hat{\imath}$

al-Lughah al-'Arabiyyah, (Madinah: Nadi al-Madinah al-Munawwarah al-Adabi, 1998), h. 5.

al-Rukâbi, Jaudat, Thuruq Tadrîs al-Lughah al-'Arabiyyah, Beirut: Dâr al-Fikr, 1981.

al-Shaghir, Abdul Majid, al-Ma 'rifah wa al-Sulthah î al-Tajribah al-Islâmiyyah, Kairo: al-

Hai'ah al-Mishriyyah al-'Ammah, 2010.

al-Syaibani, Umar at-Taumi, ’Ishâmât al-Muslimîn fîal-'Ulûm”, dalam Jurnal $a l-D a$ 'wah al-Islâmiyyah, Tripoli - Libia, Edisi IX, 1992.

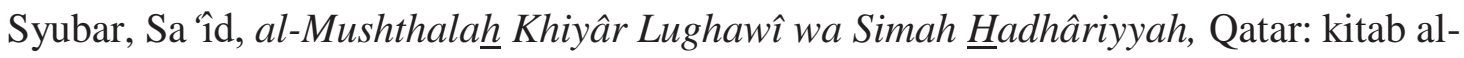
Ummah, Edisi 78), 2000.

al-Taujiry, 'Abd al- 'Azîz ibn 'Utsmân , “Juhûd al-Isisco î Nasyr al-Lughah al-Arabiyyah

Baina ghair al-Nâthiqîna bihâ", dalam Harian al-Syarq al-Awsath, Edisi 6136, Sabtu, 16 September 1995.

al-Zunaidi, 'Abd al-Rậman ibn Zaid, ㅂaqîqah al-Fikr al-Islâmi: Dirâsah Ta'shîliyyah li Ma hûm al-Fikr

al-Islâmi wa Muqawwimâtihî wa Khashâ'ishihi, Riyâdh: Dâr al-Muslim, 1995. 
